\section{Hemoglobinopathies in newborns from Salvador, Bahia, Northeast Brazil}

\author{
Hemoglobinopatias em recém-nascidos \\ de Salvador, Bahia, Nordeste do Brasil
}

\author{
Elisângela Vitória Adorno 1 \\ Fábio David Couto 1 \\ José Pereira de Moura Neto 1 \\ Joelma Figueiredo Menezes 2 \\ Marco Rêgo ${ }^{3}$ \\ Mitermayer Galvão dos Reis 1 \\ Marilda Souza Gonçalves 1,2
}

\section{Introduction}

1 Centro de Pesquisas Gonçalo Moniz, Fundação Oswaldo Cruz, Salvador, Brasil.

2 Faculdade de Farmácia, Universidade Federal da Bahia, Salvador, Brasil.

3 Faculdade Medicina, Universidade Federal da Bahia, Salvador, Brasil.

\section{Correspondence} M. S. Gonçalves Laboratório de Patologia e Biologia Molecular, Centro de Pesquisas Gonçalo Moniz, Fundação Oswaldo Cruz. Rua Waldemar Falcão 121 Salvador, $B A$ 40295-001, Brasil. mari@cpqgm.fiocruz.br

\begin{abstract}
Hemoglobinopathies are hereditary disorders of the hemoglobin molecule with a high prevalence worldwide. Brazil has a prevalence of 0.1 to $0.3 \%$ of newborns with sickle cell anemia and 20.0 to $25.0 \%$ of heterozygous $\alpha_{2}$ thalassemia among African Brazilians. In the present study, we investigated the presence of variant hemoglobins and $\alpha_{2} 3.7 \mathrm{~Kb}$ and $\alpha_{2} 4.2 \mathrm{~Kb}$ thalassemia in newborns from Salvador, Bahia, Brazil. Samples of umbilical cord blood from a total of 590 newborns were analyzed, of which 57 (9.8\%) were FAS; 36 (6.5\%) FAC; one (0.2\%) SF; and five (0.9\%) FSC. One hundred fourteen (22.2\%) newborns had $\alpha_{2} 3.7 \mathrm{~Kb}$ thalassemia, of whom 101 (19.7\%) were heterozygous and 13 (2.5\%) homozygous, showing statistical significance for hematological data between newborns with normal $\alpha$ genes and $\alpha_{2}{ }^{3.7} \mathrm{~Kb}$ thalassemia carriers. The $\alpha_{2} 4.2 \mathrm{~Kb}$ thalassemia was not found. Frequencies found in the present study confirm that hemoglobinopathies are a public health problem in Brazil, emphasizing the need for neonatal screening and genetic counseling programs.
\end{abstract}

Hemoglobinopathies; Sickle Cell Anemia; Thalassemia; Newborn Infant
Hemoglobinopathies are genetic globin gene disorders, characterized by the presence of variant hemoglobin and a decrease or absence of globin chain synthesis, known as thalassemia 1,2.

Hemoglobin $\mathrm{S}$ is the most common variant hemoglobin, and results from a single amino acid substitution of valine for glutamic acid at the sixth position of the $\beta$-globin chain; sickle cell anemia carriers are characterized by homozygosity of S hemoglobin. The hemoglobin $S$ gene has a high frequency among Africans and African descendents, as well as in India, Greece, and the United States ${ }^{3}$. Primary studies in Brazil revealed a high prevalence of hemoglobin disorders. The sickle cell trait (AS) was reported in $6.6 \%$ of blacks in the State of São Paulo, in Southeast Brazil 4. When the study was extended to the general population, frequencies of $2.7 \%$ of AS and $0.09 \%$ of sickle cell disease $(0.07 \%$ HbSS and $0.02 \%$ HbSC) were observed. These frequencies varied widely according to the degree of racial admixture in the different regions of the country. In the South of Brazil, a frequency of $1.2 \%$ of $\mathrm{HbS}$ gene was shown among newborns 5 . On the other hand, in the Northeast, frequencies of $5.1 \%$ of sickle cell trait (FAS) and $0.2 \%$ with sickle cell disease (FSC) were reported among newborns in the State of Pernambuco 6 and the State of Bahia, the frequency of AS genotype varies from $7.4 \%$ 
to $15.7 \%$, according to the population group studied 7 .

Hemoglobin $\mathrm{C}(\mathrm{HbC})$ is a variant hemoglobin in which lysine replaces glutamic acid at the sixth amino acid position of the $\beta$-globin chain 2 . HbC has a prevalence of $3 \%$ among AfricanAmericans and about 1-3\% among Puerto Ricans 8,9. In Brazil, HbC is the second most common variant hemoglobin and has been found around $2.2 \%$ to $5.2 \%$ when the heterozygous genotype (AC) has been considered in Bahia 7.

Thalassemia syndromes are found worldwide, especially $\alpha$ - and $\beta$-thalassemia 10,11 . In Southeast Brazil, a frequency of $1.3 \%$ of $\beta$-thalassemia trait and $0.1 \%$ of $\beta$-thalassemia major was reported for the general population 12 , while $\alpha_{2}$-thalassemia by a $3.7 \mathrm{~kb}$ DNA deletion $\left(\alpha_{2} 3.7 \mathrm{~Kb}\right.$-thalessemia) varied from $20.0 \%$ to $25.0 \%$ in black populations 13, and Borges et al. 14 found $49.9 \%$ of $\alpha$-thalassemia in adult outpatients seen at the University of Campinas Hospital with microcytosis and hypochromia without anemia. In the Northeast, $\alpha_{2} 3.7 \mathrm{~Kb}$-thalessemia was investigated in 106 pregnant women with AC and AA hemoglobin pattern, showing a $21.7 \%$ heterozygous and $0.9 \%$ homozygous rate for this alteration 15 .

The Consensus Conference Panel convened by the National Institutes of Health (United States) in 1987 recommended newborn screening for hemoglobinopathies in order to decrease morbidity and mortality associated with sickle cell disease. Streptococcus pneumoniae is a common cause of death in sickle cell patients and the early diagnosis of sickle cell disease could alert clinicians to potential clinical complications of the disease and allow prompt clinical care and prophylactic therapy with vaccines and antibiotics 16,17.

In Brazil, not all States have consolidated neonatal screening programs for hemoglobinopathies, despite a ruling mandating them by the Ministry of Health in June 2001 (Portaria GM/MS 822 - Diário Oficial da União 2001; 7 jun). The sickle cell disease screening program in Minas Gerais State was considered a model for South America by Serjeant 18. This program found $3.2 \%$ of screened babies with sickle cell trait, $1.3 \%$ heterozygous for $\mathrm{HbC}$, and $0.08 \%$ with sickle cell disease. Other States have developed excellent newborn screening programs, such as Bahia, Pernambuco, Maranhão, the Federal District (Brasília), São Paulo, Rio de Janeiro, Espírito Santo, Santa Catarina, Paraná, Mato Grosso do Sul, and Rio Grande do Sul
(Technical Advisory Group on Neonatal Screening, Ministry of Health, Brazil). In California (United States), a newborn hemoglobinopathy screening program evaluated two million newborns and found 492 with sickle cell disease, while 290 had hemoglobinopathy SS, 143 SC, and $47 \mathrm{~S} \beta+$ thalassemia 19 . The screening programs' implementation is an important step for increasing survival, reducing hospitalization, and minimizing expenses associated with sickle cell disease 20,21. Based on the high frequency of hemoglobinopathies in Salvador, Bahia, Brazil, we investigated the presence of variant hemoglobin and $\alpha_{2} 3.7 \mathrm{~Kb}$ and $\alpha_{2} 4.2 \mathrm{~Kb}$ thalassemias among newborns babies in order to identify potential associations between hemoglobin abnormalities and hematological characteristics.

\section{Material and methods}

\section{Casuistic}

From February to June 2000, a cross-sectional epidemiological study analyzed 590 neonates delivered by vaginal birth at the Tsylla Balbino Maternity Clinic located in Salvador, Bahia, Brazil. Information about newborns and gestational age was obtained from mothers by a questionnaire and patient records.

Newborns with gestational age less than thirty-eight weeks were considered premature 22 . Racial composition was determined by observation of facial characteristics and color of mammillae and scrotum 23.

\section{Samples}

Umbilical cord blood samples were collected by midwives under supervision of maternity clinic physician staff. After clamping, blood was drawn into a Vacutainer tube (Becton-Dickinson - Corkeysville, Maryland, United States) containing EDTA and transported to the Pathology and Molecular Biology Laboratory, Gonçalo Moniz Research Center, Oswaldo Cruz Foundation (FIOCRUZ). Hematological analysis was performed by automated cell counter (Coulter T-890 - Coulter Corporation, Florida, United States) and DNA was isolated from leukocytes (GFXTM Genomic Blood DNA Purification KIT Amersham Pharmacia Biotech, United States). 


\section{Hemoglobin profile}

Hemoglobin profile was analyzed by High Performance Liquid Chromatography - HPLC Variant Hemoglobin Testing System (Bio-Rad Laboratories - California, United States). HPLC analyses were interpreted by comparing peak retention times with those obtained for the AFCS control, utilizing the sickle cell kit for hemoglobin screening in newborns.

\section{$\alpha^{2}$-Thalassemia}

The $-\alpha_{2}{ }^{3.7 \mathrm{~Kb}}$ and $-\alpha_{2} 4.2$ deletions were identified by polymerase chain reaction (PCR), using specific primers and reaction conditions as previously described 24 .

\section{Statistical analysis}

The statistical analyses were conducted in the Epi Info software, version 6.04. Statistical significance was established at $P \leq 0.05$.

\section{Ethical considerations}

The study was approved by the Institutional Review Board/Ethics Committee of the Gonçalo Moniz Research Center, FIOCRUZ, after the newborn's parent or guardian had signed the informed consent form.

\section{Results}

The Tsylla Balbino Maternity Clinic is the largest public maternity ward in Salvador. During the study period, 2,958 children were born and 590 newborns (19.9\% of total birth cohort) were analyzed, after statistical sample calculation. Of those analyzed, 63 (10.8\%) had premature delivery and $523(89.2 \%)$ had normal gestational age; 296 (51.3\%) were female and 281 (48.7\%) male. Racial composition was determined for 578 babies: 98 (17.0\%) were classified as white, $309(53.4 \%)$ as mulatto, and $171(29.6 \%)$ as black. Mean weight was $3.152 \mathrm{~kg}( \pm 0.530)$.

\section{Hematological data and hemoglobin profiles}

Hemoglobin profiles were determined in 581 of the 590 newborns: $480(82.6 \%)$ had the normal profile FA, and 101 (17.4\%) presented variant hemoglobins, of which 57 (9.8\%) were heterozygous for $\mathrm{HbS}$ (FAS), and $38(6.5 \%)$ were heterozygous for $\mathrm{HbC}$ (FAC). One $(0.2 \%)$ baby was homozygous for $\mathrm{HbS}$ (FS) and five (0.9\%) were double heterozygous for $\mathrm{HbS}$ and $\mathrm{HbC}$ (FSC).

There was no statistical difference in the gestational ages of newborns with respect to normal and variant hemoglobin patterns. The racial distribution and hemoglobin types of 502 newborns are shown in Table 1 . Of the 47 newborns found to have the FAS pattern, 24 (51.1\%) were mulatto, 15 (31.9\%) were black, and eight $(17.0 \%)$ were white.

Newborns with normal and variant hemoglobin had statistically similar hematological characteristics, except for the FA and FAC groups, which were statistically different for PVC, RBC, and MCHC values, with p-values of $0.031,0.003$, and 0.0009, respectively (Table 2).

\section{$\alpha_{2}$ thalassemia analyses}

Of the 590 newborns, 514 were analyzed for $\alpha_{2}$ thalassemia: $400(77.8 \%)$ had normal $\alpha$-genes $(\alpha \alpha / \alpha \alpha)$ and $101(19.7 \%)$ were heterozygous $(\alpha / \alpha \alpha)$ and $13(2.5 \%)$ homozygous $(-\alpha / \alpha-)$ for the $\alpha_{2}{ }^{3.7 \mathrm{~Kb}}$ deletion. There was no statistical difference between presence of $\alpha_{2}{ }^{3.7 \mathrm{~Kb}}$ thalassemia and premature delivery.

Table 1

Ethnic characteristics and hemoglobin frequencies in newborns from the Tsylla Balbino Maternity Clinic. Salvador, Bahia, Brazil.

\begin{tabular}{|c|c|c|c|c|c|c|c|c|c|c|}
\hline \multirow[t]{3}{*}{ Racial group } & \multicolumn{10}{|c|}{ Hemoglobin profile } \\
\hline & \multicolumn{2}{|c|}{ FA } & \multicolumn{2}{|c|}{ FAS } & \multicolumn{2}{|c|}{ FAC } & \multicolumn{2}{|c|}{ FSC } & \multicolumn{2}{|c|}{ FS } \\
\hline & $\mathrm{n}$ & $\%$ & $\mathrm{n}$ & $\%$ & $\mathrm{n}$ & $\%$ & $n$ & $\%$ & $\mathrm{n}$ & $\%$ \\
\hline White $(n=86)$ & 76 & 18.2 & 8 & 17.0 & 2 & 6.0 & - & - & - & - \\
\hline Mulatto $(n=274)$ & 227 & 54.4 & 24 & 51.1 & 19 & 57.6 & 3 & 75.0 & - & - \\
\hline Black $(n=142)$ & 114 & 27.4 & 15 & 31.9 & 12 & 36.4 & 1 & 25.0 & 1 & 100.0 \\
\hline Total $(n=502)$ & 417 & 100.0 & 47 & 100.0 & 33 & 100.0 & 4 & 100.0 & 1 & 100.0 \\
\hline
\end{tabular}


Among the 114 newborns identified as $\alpha_{2}{ }^{3.7 \mathrm{~Kb}}$ thalassemia carriers, 21 (18.4\%) were whites, 57 $(50.0 \%)$ were mulattos, and $36(31.6 \%)$ blacks. Table 3 shows the statistical analysis of hematological parameters of newborns with normal $\alpha$-genes and $\alpha_{2} 3.7 \mathrm{~Kb}$ thalassemia carriers.

Analysis of hemoglobin profiles and presence of $\alpha_{2}{ }^{3.7 \mathrm{~Kb}}$ thalassemia was performed on 451 of 590 newborns. Of the 377 newborns with FA pattern, 295 (78.2\%) had normal $\alpha$-genes, 72 (19.1\%) were heterozygous, and ten $(2.7 \%)$ homozygous.

Of the 43 newborns with FAS profile, 32 (74.4\%) had normal $\alpha$-genes, nine $(20.9 \%)$ were heterozygous, and two (4.7\%) were homozygous; of the 27 newborns with pattern FAC, 22 (81.5\%) had normal $\alpha$-genes and five (18.5\%) were heterozygous; among the four newborns with FSC pattern, three $(75.0 \%)$ had normal $\alpha$ genes and one $(25.0 \%)$ was heterozygous for $\alpha_{2} 3.7 \mathrm{~Kb}$ thalassemia. The newborn with FS pattern had normal $\alpha$-genes.

Table 4 shows the hematological data from newborns with normal and variant hemoglobin genotypes, as well as for $\alpha_{2}{ }^{3.7 \mathrm{~Kb}}$ thalassemia carriers.

There was no statistical difference in the hematological characteristics of newborns with

Table 2

Hematological data and hemoglobin profile among newborns from the Tsylla Balbino Maternity Clinic.

Salvador, Bahia, Brazil.

\begin{tabular}{|c|c|c|c|c|c|c|}
\hline \multirow{2}{*}{$\begin{array}{l}\text { Hemoglobin } \\
\text { pattern }\end{array}$} & \multicolumn{6}{|c|}{ Hematological data (mean \pm SD) } \\
\hline & PCV (\%) & $\mathrm{RBC}\left(\times 10^{6} \mathrm{~mL}\right)$ & $\mathrm{Hb}(\%)$ & $\mathrm{MCV}(\mathrm{fL})$ & $\mathrm{MCH}(\mathrm{pg})$ & $\mathrm{MCHC}(\mathrm{g} / \mathrm{dL})$ \\
\hline $\mathrm{FA}(\mathrm{n}=480)$ & $46.55( \pm 6.11)$ & $4.31( \pm 0.56)$ & $14.76( \pm 1.79)$ & $108.42( \pm 6.20)$ & $34.53( \pm 5.70)$ & $31.82( \pm 2.68)$ \\
\hline \multirow[t]{2}{*}{ FAS $(n=57)$} & $45.38( \pm 5.97)$ & $4.19( \pm 0.53)$ & $14.57( \pm 1.92)$ & $108.40( \pm 6.42)$ & $34.89( \pm 2.80)$ & $32.17( \pm 1.57)$ \\
\hline & $p=0.18^{*}$ & $p=0.15^{\star}$ & $p=0.44$ * & $p=0.99 *$ & $p=0.38^{*}$ & $P=0.66^{\star \star}$ \\
\hline FA $(n=480)$ & $46.55( \pm 6.11)$ & $4.31( \pm 0.56)$ & $14.76( \pm 1.79)$ & $108.42( \pm 6.20)$ & $34.53( \pm 5.70)$ & $31.82( \pm 2.68)$ \\
\hline \multirow[t]{2}{*}{ FAC $(n=38)$} & $43.37( \pm 7.73)$ & $4.02( \pm 0.71)$ & $14.44( \pm 1.72)$ & $107.95( \pm 4.11)$ & $36.78( \pm 6.84)$ & $34.13( \pm 6.68)$ \\
\hline & $p=0.031 * \star$ & $p=0.003^{*}$ & $p=0.27^{*}$ & $p=0.25^{\star \star}$ & $p=0.23^{\star \star}$ & $p=0.0009^{\star *}$ \\
\hline $\mathrm{FA}(\mathrm{n}=480)$ & $46.55( \pm 6.11)$ & $4.31( \pm 0.56)$ & $14.76( \pm 1.79)$ & $108.42( \pm 6.20)$ & $34.53( \pm 5.70)$ & $31.82( \pm 2.68)$ \\
\hline \multirow[t]{2}{*}{$\operatorname{FSC}(n=5)$} & $48.75( \pm 5.56)$ & $4.45( \pm 0.47)$ & $14.73( \pm 1.58)$ & $109.55( \pm 5.45)$ & $33.45( \pm 4.98)$ & $30.55( \pm 4.20)$ \\
\hline & $p=0.47^{*}$ & $p=0.62^{\star}$ & $p=0.96^{*}$ & $p=0.72^{\star}$ & $p=0.56^{*}$ & $p=0.34^{*}$ \\
\hline
\end{tabular}

* ANOVA; ** Kruskal-Wallis $\mathrm{H}$.

$\mathrm{PCV}=$ Packed cell volume; $\mathrm{RBC}=$ Red blood cells; $\mathrm{Hb}=$ Hemoglobin; $\mathrm{MCV}=$ Mean cell volume;

$\mathrm{MCH}=$ Mean cell hemoglobin; $\mathrm{MCHC}=$ Mean cell hemoglobin concentration

Table 3

Hematological data and $\alpha$ genes status among newborns from the Tsylla Balbino Maternity Clinic.

Salvador, Bahia, Brazil.

\begin{tabular}{|c|c|c|c|}
\hline $\begin{array}{l}\text { Hematological data } \\
\text { (mean } \pm \text { SD) }\end{array}$ & $\begin{array}{l}\text { Normal } \alpha \text {-genes } \\
\quad(n=400)\end{array}$ & $\begin{array}{l}-\alpha_{2}^{3.7 \mathrm{~Kb}} \text { thalassemia carriers } \\
\qquad(\mathrm{n}=114)\end{array}$ & P-value \\
\hline PCV (\%) & $46.98( \pm 5.97)$ & $44.90( \pm 6.72)$ & $0.002^{\star}$ \\
\hline $\mathrm{RBC}(\times 106 / \mathrm{mL})$ & $4.26( \pm 0.54)$ & $4.41( \pm 0.65)$ & $0.002^{\star \star}$ \\
\hline $\mathrm{Hb}(\mathrm{g} / \mathrm{dL})$ & $14.09( \pm 1.69)$ & $14.26( \pm 1.72)$ & $0.00009 *$ \\
\hline $\operatorname{MCV}(f L)$ & $110.23( \pm 4.43)$ & $102.78( \pm 6.25)$ & $<0.00001^{\star \star}$ \\
\hline $\mathrm{MCH}(\mathrm{pg})$ & $35.36( \pm 3.78)$ & $32.64( \pm 3.49)$ & $<0.00001^{\star *}$ \\
\hline $\mathrm{MCHC}(\mathrm{g} / \mathrm{dL})$ & $32.10( \pm 3.14)$ & $31.76( \pm 2.87)$ & $0.30 *$ \\
\hline
\end{tabular}

* ANOVA; ${ }^{* *}$ Kruskal-Wallis $\mathrm{H}$.

$\mathrm{PCV}=$ Packed cell volume; RBC = Red blood cells; $\mathrm{Hb}=$ Hemoglobin; $\mathrm{MCV}=$ Mean cell volume;

$\mathrm{MCH}=$ Mean cell hemoglobin; $\mathrm{MCHC}=$ Mean cell hemoglobin concentration. 
Hematological data and hemoglobin profile among newborns with $\alpha_{2}{ }^{3.7 K b t h a l a s s e m i a ~}$ from the Tsylla Balbino Maternity Clinic. Salvador, Bahia, Brazil.

\begin{tabular}{|c|c|c|c|c|c|c|}
\hline \multirow{2}{*}{$\begin{array}{l}\text { Hemoglobin } \\
\text { pattern }\end{array}$} & \multicolumn{6}{|c|}{ Hematological data (mean \pm SD) } \\
\hline & PVC & $\mathrm{RBC}(\times 106 / \mathrm{mL})$ & $\mathrm{Hb}(\%)$ & $\mathrm{MCV}(\mathrm{fL})$ & $\mathrm{MCH}(p g)$ & $\mathrm{MCHC}(\mathrm{g} / \mathrm{dL})$ \\
\hline $\mathrm{FA}(\mathrm{n}=82)$ & $45.47( \pm 5.96)$ & $4.51( \pm 0.55)$ & $14.38( \pm 1.47)$ & $102.09( \pm 6.39)$ & $32.08( \pm 2.67)$ & $31.41( \pm 1.67)$ \\
\hline \multirow[t]{2}{*}{ FAS $(n=11)$} & $41.99( \pm 8.15)$ & $4.04( \pm 0.82)$ & $13.63( \pm 2.41)$ & $104.41( \pm 4.18)$ & $34.16( \pm 4.03)$ & $32.66( \pm 3.16)$ \\
\hline & $p=0.09 *$ & $p=0.01^{*}$ & $p=0.47^{\star \star}$ & $p=0.25^{\star}$ & $p=0.03^{\star}$ & $p=0.29 * \star$ \\
\hline $\mathrm{FA}(\mathrm{n}=82)$ & $45.47( \pm 5.96)$ & $4.51( \pm 0.55)$ & $14.38( \pm 1.47)$ & $102.09( \pm 6.37)$ & $32.08( \pm 2.67)$ & $31.41( \pm 1.67)$ \\
\hline \multirow[t]{2}{*}{ FAC $(n=5)$} & $39.10( \pm 11.79)$ & $3.75( \pm 10.9)$ & $13.56( \pm 2.30)$ & $103.92( \pm 4.01)$ & $39.09( \pm 9.30)$ & $36.66( \pm 10.15)$ \\
\hline & $p=0.11 \star \star$ & $p=0.11 * \star$ & $p=0.25^{\star}$ & $p=0.53^{*}$ & $p=0.031 * \star$ & $p=0.018^{\star \star}$ \\
\hline
\end{tabular}

* ANOVA; ${ }^{* *}$ Kruskal-Wallis $\mathrm{H}$.

FA and FSC hemoglobin profile and thalassemia $\alpha_{2}{ }^{3.7 \mathrm{~Kb}}$ carriers.

\section{Discussion}

The frequencies of variant hemoglobin found in this study (Hb FAS 9.8\%; Hb FAC 6.5\%; FS $0.2 \%$, and FSC $0.9 \%$ ) are the highest described in Brazil. The high frequencies of variant hemoglobin are probably due to the high rate of racial admixture in the Bahian population, with a strong African gene component introduced by the African slave trade in Brazil. Furthermore, the Tsylla Balbino Maternity ward serves the majority of low-income women in Salvador, who are almost exclusively blacks or mulattos 23. Among the newborns analyzed, only six (5 FSC and 1 FS) required special care, representing the symptomatic group that can develop severe clinical conditions and need early treatment. The 47 newborns identified as FAS displayed a racial distribution of $17.0 \%$ whites, $53.4 \%$ mulattos and $29.6 \%$ blacks. These variations of racial distribution of hemoglobin $\mathrm{S}$ among the newborns groups highlight the need for universal neonatal hemoglobinopathy screening in the Brazilian population. The comparison of hematological data among newborns with $\mathrm{HbC}$ and those with normal hemoglobin showed statistical significance for PVC, RBC, and MCHC due to increased blood viscosity, demonstrating the influence of $\mathrm{HbC}$ on hematological parameters 8,9 .

The high frequencies of $\alpha_{2}{ }^{3.7 \mathrm{~Kb}}$ thalassemia (heterozygous $19.7 \%$; homozygous $2.5 \%$ ) are similar to those found in previous studies conducted in Brazilian populations 11. The presence of $\alpha_{2} 3.7 \mathrm{~Kb}$ thalassemia was not associated with premature delivery. However, van der Dijs et al. 25 speculated that the presence of $\alpha_{2}$ thalassemia could decrease the capacity to extract oxygen from maternal circulation and could thus be a contributing factor to early delivery of newborn $\alpha_{2}$ thalassemia carriers. Newborns with FAS and FAC pattern, such as the babies heterozygous for $\alpha_{2}{ }^{3.7 \mathrm{~Kb}}$ thalassemia, did not present symptoms of severe anemia. However, they still need genetic counseling 26 .

We did not identify any newborns with $\alpha_{2} 4.2 \mathrm{~Kb}$ thalassemia in our study, suggesting that this type of thalassemia is rare or absent in Bahia. The frequency of $\alpha_{2} 3.7 \mathrm{~Kb}$ thalassemia among FAS newborns $20.9 \%$ of which were heterozygous and $4.7 \%$ of which were homozygous) could be beneficial for these $\mathrm{S}$ hemoglobin carriers and for the sickle cell anemia patients in Bahia. The $\alpha_{2}$ thalassemia is considered a beneficial factor, since this condition is associated with less severe clinical manifestations among sickle cell disease carriers 8,9 . It decreases MCHC and the rate of hemolysis, resulting in higher $\mathrm{Hb}, \mathrm{PCV}$, and RBC values. Therefore, some complications such as leg ulcers, renal pathology, and strokes become less frequent. However, the frequency of other complications such as osteonecrosis and retinopathy may be increased 27 .

The comparison of hematological data among newborns with $\alpha$-normal genes and those with $\alpha_{2}{ }^{3.7 \mathrm{~Kb}}$ thalassemia showed statistical differences in all hematological parameters analyzed, except for MCHC. The hematological analysis of newborns with FA and FAS hemoglobin groups and $\alpha_{2}{ }^{3.7 \mathrm{~Kb}}$ thalassemia carriers showed statistically significant differences in $\mathrm{RBC}$ and $\mathrm{MCH}$; the comparison of the FA and FAC groups and $\alpha_{2}{ }^{3.7 \mathrm{~Kb}}$ thalassemia carriers 
showed significant differences in $\mathrm{MCH}$ and MCHC. The hematological differences found between newborns with normal $\alpha$-genes and $\alpha_{2} 3.7 \mathrm{~Kb}$ thalassemia carriers could be intensified by the presence of variant hemoglobins. Furthermore, differentiation within the Bahian pediatric population needs to be developed in order to determine whether the presence of $\alpha_{2}{ }^{3.7 \mathrm{~Kb}}$ thalassemia could be responsible for intensifying the hematological pattern of ane- mia, especially in child with iron deficiency, avoiding erroneous therapy.

In Bahia, the presence of hemoglobinopathies is a public health problem, and the early diagnosis of variant hemoglobin carriers provides an opportunity for counseling and early clinical follow-up of the child, both of which contribute to reduce child morbidity and mortality rates.

\section{Resumo}

Hemoglobinopatias são alterações hereditárias na molécula de hemoglobina com prevalência mundial elevada. O Brasil apresenta prevalência de 0,1 a 0,3\% para recém-nascidos com anemia falciforme e freqüência de 20,0 a 25,0\% para a ocorrência de heterozigotos da talassemia $\alpha_{2}$ entre individuos afro-descendentes. O presente estudo investigou a presença de hemoglobinas variantes e talassemia $\alpha_{2}{ }^{3.7 K b}$ e $\alpha_{2}{ }_{2}^{4.2 K b}$ em recém-nascidos de Salvador, Bahia, Brasil. Analisamos o sangue do cordão umbilical de 590 recémnascidos, sendo 57 (9,8\%) com padrão FAS; 36 (6,5\%) FAC; um (0,2\%) SF e cinco (0,9\%) FSC. Cento e catorze (22,2\%) apresentaram talassemia $\alpha_{2} 3.7 \mathrm{~Kb}$, dos quais 101 (19,7\%) foram heterozigotos e 13 (2,5\%) homozigotos, mostrando significância estatística para os dados hematológicos entre recém-nascidos com genes $\alpha$ normais e portadores de talassemia $\alpha_{2}{ }^{3.7 K b}$. A talassemia $\alpha_{2}{ }^{4.2 K b}$ não foi encontrada. As freqüencias descritas neste trabalho confirmam que as hemoglobinopatias são um problema de Saúde Pública no Brasil, enfatizando a importância dos programas de triagem neonatal e aconselhamento genético.

Hemoglobinopatias; Anemia Falciforme; Talassemia; Recém-Nascido

\section{Contributors}

E. V. Adorno participated in the blood sample collection in the hospital, hemoglobin analysis, DNA extraction, molecular analysis, and drafting of the manuscript. F. D. Couto, J. F. Menezes and J. P. Moura Neto participated in the blood sample collection in the hospital, hemoglobin analysis, and DNA extraction. M. Rego participated in the statistical analysis. M. G. Reis participated in the interpretation of the results and drafting and revision of the manuscript. M. S. Gonçalves supervised the laboratory analysis, interpretation of the results, and drafting and revision of the manuscript.

\section{Acknowledgments}

We wish to thank all the parents for allowing their newborns to participate in the study, Dr. Edeltrudes do Espírito do Santo (head of the Tsylla Balbino Maternity Clinic), the clinical staff who helped with sample collection, and Craig Milroy and Fabíola Nascimento da Conceição, who reviewed the English version of this article. 


\section{References}

1. Weatherall DJ, Provan AB. Red cells I: inherited anaemias. Lancet 2000; 355:1169-75.

2. Bunn HF. Sickle hemoglobin and other hemoglobin mutants. In: Stamatoyannopoulos G, Nienhuis AW, Majerus PW, Varnus H, editors. The molecular basis of blood diseases. Philadelphia: WB Saunders Co.; 1994. p. 207-56.

3. Embury SH. Sickle cell disease. In: Hoffman R, Benz Jr. EJ, Shattil EJ, Furie B, Cohen HJ, Silberstein LE, editors. Hematology. New York: Churchill Livingstone; 1995. p. 611-40.

4. Ramalho AS, Jorge RN, Oliveira JA, Pedreira DA. Hemoglobina $S$ em recém-nascidos brasileiros. J Pediatr 1976; 41:9-10.

5. Daudt LE, Zechmaister D, Portal L, Camargo Neto E, Silla LMR, Giugliani R. Triagem neonatal para hemoglobinopatias: um estudo piloto em Porto Alegre, Rio Grande do Sul, Brasil. Cad Saúde Pública 2002; 18:833-41.

6. Bandeira FMGC, Leal MC, Souza RR, Furtado VC, Gomes YM, Marques NM. Características de recém-nascidos portadores de hemoglobina "S" detectados através de triagem em sangue de cordão umbilical. J Pediatr (Rio J) 1999; 75:167-71.

7. Azevêdo ES, Alves AFP, Silva MCBO, Souza MGF, Lima AMVMD, Azevêdo WC. Distribution of abnormal hemoglobins and glucose-6-phosphate dehydrogenase variants in 1200 school children of Bahia, Brazil. Am J Phys Anthropol 1980; 53:509-12.

8. Lukens JN. The abnormal hemoglobins: general principles. In: Lee CW, Foster J, Lukens J, Paraskevas F, Greer JP, Rodgers GM, editors. Wintrobe's Clinical Hematology. Baltimore: Williams \&Wilkins; 1999. p. 1329-45.

9. Lukens JN. Thalassemia and related disorders: quantitative disorders of hemoglobin synthesis. In: Lee CW, Foster J, Lukens J, Paraskevas F, Greer JP, Rodgers GM, editors. Wintrobe's Clinical Hematology. Baltimore: Williams \& Wilkins; 1999. p. 1405-48.

10. Steinberg MH, Embury SH. $\alpha$-Thalassemia in blacks: genetic and clinical aspects and interactions with the sickle hemoglobin gene. Blood 1986; 68:985-90.

11. Wenning MRSC, Kimura EM, Costa FF, Saad STO, Gervásio S, De Jorge SB, et al. $\alpha$-Globin genes: thalassemic and structural alterations in a Brazilian population. Braz J Med Biol Res 2000; 33: 1041-5.

12. Ramalho AS, Silva RBP, Teixeira RC, Compri MB. Hemoglobin screening: response of a Brazilian community to optional programs. Cad Saúde Pública 1999; 15:591-5.

13. Sonati MF, Farah SB, Ramalho AS, Costa FF. High prevalence of alpha-thalassemia in a black population of Brazil. Hemoglobin 1991; 15:309-11.
14. Borges E, Wenning MRSC, Kimura EM, Gervásio SA, Costa FF, Sonati MF. High prevalence of alpha-thalassemia among individuals with microcytosis and hypochromia without anemia. Braz J Med Biol Res 2001; 34:759-62.

15. Couto FD, Albuquerque AB, Adorno EV, Moura Neto JP, Abbehusen LF, Oliveira JL, et al. Alphathalassemia 2, 3.7 Kb deletion and hemoglobin AC heterozygosity in pregnancy: a molecular and hematological analysis. Clin Lab Haematol 2003; 25:29-34.

16. Vichinsky E, Hurst D, Earles A. Newborn screening for sickle cell disease: effect on mortality. Pediatrics 1988; 81:749-55.

17. Joiner $\mathrm{CH}$. Universal newborn screening for hemoglobinopathies. J Pediatr 2000; 136:145-6.

18. Serjeant GR. Screening for sickle-cell disease in Brazil. Lancet 2000; 356:168-9.

19. Shafer FE, Lorey F, Cunningham GC, Klumpp C, Vinckinsky E, Lubin B. Newborn screening for sickle cell disease: 4 years of experience from California's newborn screening program. J Pediatr Hematol Oncol 1996; 8:36-41.

20. Bardakdjian-Michau J. Neonatal detection of sickle cell disease. J Gynecol Obstet Biol Reprod (Paris) 2003; 3232 (1 Suppl):1S61-4.

21. Bardakdjian-Michau J, Guilloud-Batailie M, MaierRedelsperger M, Elion J, Girot R, Feingold J, et al. Decreased morbidity in homozygous sickle cell disease detected at birth. Hemoglobin 2002; 26: 211-7.

22. Diniz EMA. Manual de neonatologia. Rio de Janeiro: Revinter; 1994.

23. Azevêdo ES. Subgroup studies of black admixture within a mixed population of Bahia, Brazil. Ann Human Genet 1980; 44:55-60.

24. Dodé C, Krishnamoorthy R, Lamb J, Rochete J. Rapid analysis of alpha 3.7 thalassemia and alpha alpha alpha anti 3.7 triplication by enzymatic amplification analysis. Br J Haematol 1993; 83:10511.

25. van der Dijs FPL, van den Berg GA, Scherner JG, Muskiet FD, Landman H, Muskiet FAJ. Screening cord blood for hemoglobinopathies and thalassemia by HPLC. Clin Chem 1992; 38:1864-9.

26. Adams RJ, Kutlar A, McKie V, Carl E, Nichols FT, Liu JC, et al. Alpha thalassemia and stroke risk in sickle cell anemia. Am J Hematol 1994; 45:279-82.

27. Ramalho AS, Magna LA, Paiva-e-Silva RB. A portaria no 822/01 do Ministério da Saúde e as peculiaridades das hemoglobinopatias em saúde pública no Brasil. Cad Saúde Pública 2003; 19:1195-9.

Submitted on 28/May/2003

Final version resubmitted on 18/Feb/2004

Approved on 01/Mar/2004 